\title{
Röntgenographische und optische Untersuchung der Umwandlung Albit-Analbit-Monalbit
}

\section{Doctoral Thesis}

Author(s):

Schneider, Toni Rudolf

Publication date:

1957

Permanent link:

https://doi.org/10.3929/ethz-a-000091214

Rights / license:

In Copyright - Non-Commercial Use Permitted 
Prom. Nr. 2700

\title{
Röntgenographische und optische Untersuchung der Umwandlung Albit-Analbit-Monalbit
}

von der

\author{
EIDGENÖSSISCHEN TECHNISGHEN \\ HOCHSCHULE IN ZÜ RICH \\ zur Erlangung \\ der Würde eines Doktors der Naturwissenschaften \\ genehmigte
}

PROMOTIONSARBEIT

vorgelegt von

TONI RUDOLF SCHNEIDER

von Vechigen (Kt. Bern)

Referent: Herr Prof. Dr. F. LAves

Korreferent: Herr Prof. Dr. C. Burni

WIESBADENER GRAPHISCHE BETRIEBE GMBH - WIESBADEN 


\title{
Röntgenographische und optische Untersuchung der Umwandlung Albit-Analbit-Monalbit
}

\author{
Von TONI R. SCHNEIDER
}

Mit 17 Abbildungen im Text

(Eingegangen am 28. April 1957)

\begin{abstract}
An investigation has been carried out of the variation of some properties of soda-rich plagioclases as a function of heating time at several temperatures $\left(950^{\circ}\right.$, $1000^{\circ}, 1050^{\circ} \mathrm{C}$ ). The following properties were measured: 1. lattice angles, 2. orientation of the indicatrix, 3. optical axial angle $2 V, 4$. extinetion angles, 5. homogenization of an oligoclase originally unmixed.

The initial materials were single crystals, which became submicroscopically twinned as heating proceeded. The different stages of this twinning were in. vestigated by means of $\mathrm{X}$-rays. This formation of twins is explained as a consequence of the displacive transformation monalbite/analbite that can take place after the $A l / S i$ distribution has become sufficiently disordered.

The influence of twinning on the optics of analbite is discussed. As heating proceeds the optics of analbite gradually change to "monoclinic" as a consequence of the submicroscopic twinning. New optical data are reported for untwinned analbite.
\end{abstract}

\section{Zusammenfassung}

Die Variation verschiedener Eigenschaften saurer Plagioklase wurde bei verschiedenen Temperaturen $\left(950^{\circ}, 1000^{\circ}, 1050^{\circ} \mathrm{C}\right)$ als Funktion der Erhitzungsdauer untersucht. Gemessen wurden: 1. Gitterwinkel, 2. Indikatrixlage, 3. Winkel der optischen Achsen 2V, 4. Auslöschungswinkel, 5. Homogenisierung eines ursprünglich entmischt vorliegenden Oligoklases.

Das benützte, ursprünglich einkristallin vorliegende Material verzwillingt sich submikroskopisch, zunehmend mit fortschreitender Erhitzungszeit. Die Art der Verzwillingung wurde röntgenographisch verfolgt. Sie wird als Folge der ,,displacive transformation" Monalbit/Analbit gedeutet, welche dann eintreten kann, wenn das Material infolge der Erhitzung bezüglich der $A l / S i$-Verteilung genügend ungeordnet geworden ist.

Der Einfluß der Verzwillingung auf das optische Verhalten des Analbites wird diskutiert. Mit zunehmender Erhitzungsdauer wird infolge dieser submikroskopischen Verzwillingung kontinuierlich ein „optisch monoklines“ Verhalten erreicht. Eine neue Analbit-Optik, die für unverzwillingtes Material gilt, wird mitgeteilt. 